\title{
Summary
}

Nataliia Zakharchyn. Legislative regulation of museums activity in the Second Rzechpospolita Polska.

The article considers the creation of the legislative basis regarding the museums' activity in interwar (1918-1939) Poland. Temporary organization of common government authorities in 1918 suggested subordination of museums of interwar Poland to the Ministry of religion and popular education. It also describes changes in subordination of the museums and some features of law-making process. In April 1918, the Department of Art of the Ministry processed and offered the first project of temporary law on museums. According to the legislative proposal, state politics in the museum industry had to be implemented using the special museum abstract within Department of Art. In the draft, there were a few types of museum identified: the main ones (national) and regional, educational and special.

It was necessary to legislate on determining and identifying main directions of the activity, to organizationally form the framework of their functioning, for the sake of museum professional work activization, controlling their activity, help with creation of new collections and support of some old ones. It is stated that his fact was understood by the representatives of the organizations that were either connected to museum industry or played a catalytic role in museum reforms in the interwar period, for instance, The Union of Museums of Poland. It was the Union that the draft law "Onthe trusteeship for the public museums" was prepared by. Apart from the draft law, the project of the implementing regulation to the bill regarding establishment and activity of the Museum State Council was adopted. In the article, the process of establishing the draft law is considered.

The article reflects the representation of modified law "On the trusteeship for the public museums" in the Parliament of Second Rzechpospolita Polska. In the parliament, the draft bill was considered as a framework, which determines the concept of a public museum. According to the bill, Minister of religion and education implemented the trusteeship and control of the activity of the public museums and approved theirstatutes. The article also reviews the aims and tasks of the adopted law and further implementing regulations, particularly, on the establishment of Museum State Council.

Key words: draft bill, museums, interwar Poland, bill, the Union of Museums of Poland.

DOI: $10.36695 / 2219-5521.1 .2020 .06$

УДК 340.15

\section{O.Ю. IBAHOB}

Олександр Юрійович Іванов, кандидат юридичних наук, старший викладач Національної академії Служби безпеки України*

ORCID: 0000-0002-5890-5369

\section{ІДЕОЛОГІЧНІ ТА ПОЛІТИКО-ПРАВОВІ ЗАСАДИ РОСІЙСЬКОЇ ЕКСПАНСІЇ В КАЗАХСТАНІ (1714 Р. - ПЕРША ПОЛОВИНА ХІХ СТ.)}

Історія свідчить, що зовнішня політика Росії (як теперішньої Російської Федерації (далі - РФ), так і їі політичних попередників) повсякчас була спрямована на задоволення експансіоністських цілей. Причому наявність таких цілей пов'язана зі стратегічною заінтересованістю російського керівництва у певних регіонах світу. Одним із таких регіонів для Росії була і залишається Центральна Азія (зокрема, Казахстан). Фахівці констатують, що на сьогодні російське керівництво ретельно розробляє та поетапно втілює масштабний геополітичний проєкт із відновлення колишньої імперської величі своєї держави. Разом із тим основоположні засади, на яких побудована сучасна державна політика РФ, та методи їі реалізації не є модерними. Також особливе місце посідає державницька ідеологія, котра по суті визначає експансіонізм як сенс і сутність існування російської держави.

Стратегічні інтереси Росії в центральноазійському регіоні обумовлені його сприятливим економічним становищем. Останнє виявилось особливо придатним для задоволення потреб російської зовнішньої торгівлі шляхом формування прямого виходу на азійський ринок. Попри те, що формально входження казахських земель до складу Російської імперії виглядало добровільним, насправді ці процеси були пов'язані із активними загарбницькими діями останньої. Входження казахських територій до ііі складу припало на XVIII першу чверть ХІХ ст. ст., після чого настав період їхньої цілковитої русифікації. Зважаючи на те, що колишнє Казахське ханство цікавило Росію виключно як природоресурсна база та плацдарм для подальшого просування на азійський ринок, збереження традиційного соціально-економічного укладу та сприяння подальшому розвитку його інститутів не було доцільним для росіян. Така ситуація різко контрастує із поширюваними російською пропагандою тезами щодо нібито прогресивного значення включення Казахстану до складу Російської імперії.

Дослідження проблематики включення казахських земель до складу Російської імперії та їх подальшої інкорпорації в історичній науці доволі фрагментарні. Окремі аспекти цих процесів висвітлені у дореволюційній російській науці (О. Добросмислов, А. Левшин, Л. Мейєр та ін. ${ }^{1}$ ), однак наукова об'єктивність цих праць видається доволі сумнівною з огляду на необхідність забезпечення експансіоністських потреб російського уряду тих часів. За радянської доби вивчення зазначеної тематики помітно активізувалось, але відпо-

() О.Ю. Іванов, 2020

* Oleksandr Ivanov, Ph.D. in Law, Senior Lecturer of the National Academy of the Security Service of Ukraine 
відні роботи істориків базувалися головним чином на історіографії попереднього періоду та сформованій у той же час джерельній базі. Дослідження радянських науковців можна умовно поділити на такі періоди: 1922-1939 pр. - критика колоніальної політики царизму в Казахстані, розкриття іiі асиміляторських напрямів (С. Асфендіаров 2 , С. Садаквасов та ін.); 1940-і-1970-і рр. - чітко виражене вихваляння «прогресивного» значення включення Казахстану до складу Російської імперії на тлі проголошеної радянською владою політики «дружби народів» (Н. Аполлова3 ${ }^{3}$ В. Басін4 та ін.); 1980-і - початок 1990-х рр. - викривальні дослідження щодо різновекторності російської експансії в казахських жузах та її значення для задоволення російських економічних і воєнно-стратегічних інтересів, активізація в цьому напрямі дослідницької активності представників Казахської РСР (А. Сабирханов, Б. Сулейманов 5 та ін.). У пострадянські часи дослідження зазначеної проблематики були практично повністю згорнуті та мали точковий характер. Слід також зауважити, що праці сучасних казахських істориків (3. Кабульдинова, Ж. Калієва та ін.) не відзначаються новизною залученої джерельної бази та історіографічних оцінок порівняно з їхніми радянськими та російськими попередниками. Загалом на сьогодні з огляду на особливе місце в російському геополітичному курсі Центральної Азії в цілому та Казахстану зокрема знову постає нагальна потреба в активізації таких досліджень.

Із зазначеного очевидно, що експансіоністська політика Російської імперії в Казахстані та їі ідеологічна основа завжди становили значний науковий інтерес. Однак з огляду насамперед на обмежений доступ дослідників до відповідних першоджерел недостатньою мірою висвітленими залишаються політико-правові аспекти цієї проблематики, серед іншого - нормативне забезпечення напрямів російської експансії в Казахстані та його аналіз крізь призму російської державницької ідеології на різних етапах. Зокрема, практично недослідженими є важливі питання щодо зв'язків між політико-правовими аспектами експансіоністської політики Росії та факторами соціально-економічної дійсності, які їх обумовлювали. Так, за часів Російської імперії публікація відповідних історичних джерел була лише фрагментарною в межах наукових праць. У радянський період видано кілька збірників документів з історії Казахстануб, однак там практично відсутні джерела, що викривали б дійсні політичні наміри Російської імперії при здійсненні експансії в казахському напрямі.

Виходячи із викладеного вище, метою нашої статті є висвітлення ідеологічного та політико-правового базису розробки й реалізації заходів експансіоністської політики Російської імперії у Казахстані. Нижня хронологічна межа дослідження - 1714 р. - співвідноситься із направленою Петром I до казахських степів загарбницькою експедицією. Верхньою межею - перша половина XIX ст. - $є$ час запровадження заходів російської експансіоністської політики в Казахстані та його русифікація. У контексті характеристики передумов до початку Росією експансіоністських дій щодо Казахстану до наукового аналізу залучаються і більш ранні періоди.

Із приходом до влади у Московському царстві в 1682 р. Петра I започатковані ще кількома століттями раніше тенденції до встановлення світового панування дістали більш яскраве вираження в державницькому курсі. Формально це було відображено в 1721 р. 3 проголошенням Російської імперії. Політика Петра І спрямовувалася на «прорубування вікна» до Європи, однак про «ключ і ворота» до панування в Азії новоспечений імператор також не забував. Для цієї ролі ідеально підходили землі Казахського ханства - утвореної на уламках Золотої Орди політично роздробленої держави. Загалом відлік існування самостійної державності казахів прийнято вести від середини XV ст., коли близько 1465 р. внаслідок повстання в Узбецькому ханстві кілька племен проголосили незалежність і назвали себе Казахським ханством. Строкатість як їхнього етнічного складу, так і господарської спеціалізації призвели до того, що приблизно століття потому почав складатися чітко виражений поділ ханства на жузи - самостійні військово-адміністративні одиниці, у кожній із яких існувала власна складна система управління та звичаєвого права. Ці утворення були кочовими, а тому досить часто у подальшому в офіційних документах Російської імперії вони іменувались ордами за аналогією із устроєм колишньої Монгольської імперії. У результаті згаданих процесів сформувалися Старший, Середній та Молодший жузит.

Слід зазначити, що Московське царство перманентно підтримувало економічні та політичні зв’язки із тим жузом, який на той момент володів панівним становищем щодо інших, а також надавало підтримку повстанським рухам проти місцевих правителів (наприклад, підтримка хана Таваккула у повстанні проти Бухарського ханства 1594 р.). Із цього часу по суті розпочалося встановлення російської присутності в середньоазійському регіоні (у тому числі, у казахській державі) з метою поступового його включення до сфери свого контролю. Тому можна стверджувати про те, що з кінця XVI ст. в Казахському ханстві розпочалася російська експансія - розповсюдження різновекторного впливу Московського царства (а в подальшому - i Російської імперіi) на казахські території (економічного, політичного та ін.), котрі становили для росіян значний стратегічний інтерес. Кінцевим результатом експансії стало включення складових частин ханства до складу Росії упродовж XVIII-XIX століть.

Виходячи із зазначеного вище, можна стверджувати, що досягнення фінальної мети російської експансії у Казахському ханстві розпочалося за доби правління Петра І. Так, у 1714 р. за указами царя до казахських жузів було спрямовано експедиції під проводом капітана О. Бековича-Черкаського та підполковника І. Бухгольца. Метою їх було задекларовано розвідати можливі зручні торгові шляхи до Індії, однак уже перші плоди їхньої діяльності засвідчили невідповідність дійсності цього положення: експедиції відзначалися відверто каральною спрямованістю. Поряд із жорстоким поводженням із місцевим населенням члени експедицій побудували низку воєнних укріплень уздовж річок Амудар'я і Сирдар'я, а також висунули ультиматуми ряду місцевих правителів щодо прийняття російського підданства. Відтак, відбувалося стрімке нарощування присутності Росії на казахських територіях.

Уже за доби правління імператриці Анни Іоанівни (1730-1740рр.) до складу Російської імперії було включено Молодший (1731р.) та Середній (1740р.) жузи. 3 формальної точки зору це виглядало як задово- 
лення імператрицею прохань місцевих ханів щодо взяття під захист відповідних територій, що потерпали від нападів суміжних держав, але насправді мали місце закономірні наслідки тривалого нарощування російської присутності в регіоні. У кожному випадку була видана царська грамота, де закріплювався обсяг повинностей, які жузи повинні були здійснювати в обмін на російський протекторат, а також і зобов'язання самодержавної влади щодо забезпечення їхнього безпечного існування ${ }^{8}$. Включення Старшого жуза відбулося за правління Олександра I в 1818 р. (складання присяги на вірність імператору - у 1824 р.), про що також було видано відповідну царську грамоту. Згідно з грамотами, казахи були зобов’язані «служити вірно і платити ясак (податок - О. І.)» до російської казни, а імператор проголошував про те, що казахи «на рівні $з$ підданими нашими захищені нашою імператорською величністю мають бути». Поряд із тим джерела не фіксують згадок $з$ приводу прохання правителя цього жуза російському імператору про прийняття його разом зі своїм народом до підданства Російської імперії. Саме 3 цією датою пов'язується цілковите встановлення російського контролю над територією колишнього Казахського ханства, після чого царський уряд розпочав активні заходи з русифікації регіону.

Наукові праці аж до середини ХХ ст. були наповнені порівняннями російської колоніальної системи із зарубіжними аналогами ${ }^{9}$. Зокрема, йшлося про латиноамериканські й африканські колонії, підвладні Іспанії, Португалії, Голландії, Франції та Англії. У цьому контексті основні аргументи пропагандистів зводилися до того, що названі метрополії нібито займалися лише винищенням корінного населення і безкарною експлуатацією природних ресурсів у своїх колоніях, чого, мовляв, не можна сказати про Росію. На думку цих фахівців, метою колоніальної політики Російської імперії було здійснення проголошеної Катериною II «цивілізаційної місії» зі «звільнення» і «поліпшення» умов життя «малих народів». У такий спосіб на фоні образів «жорстоких експлуататорів» Заходу через протиставлення їм формувався образ «дбайливої» російської монархії, котра переймається долями народів, які самі собі не здатні дати ради у протистоянні зовнішнім загрозам та у власному розвитку. При цьому не береться до уваги істотна відмінність між російським і західним підходами до колонізації. Разом із тим побудова управління в колоніях, що належали західним державам, здійснювалася в суворій відповідності з особливостями національного складу підкорених територій.

У цілому ж, на наш погляд, протиставлення російської колонізації західним аналогам не є коректним 3 огляду на те, що при всіх обмеженнях населення Африки і Америки, здійснюваних західноєвропейськими завойовниками, воно не піддавалося цілеспрямованій національній асиміляції. У випадку ж із Росією якраз це й було одним із найголовніших завдань експансії. Так, у ході роботи спрямованих Петром I у 1714 р. експедицій на територію сучасного Казахстану проводилося вивчення не тільки особливостей середньоазіатської торгівлі і географічного положення прилеглих до Індії територій, а й побуту місцевого населення, специфіки земельних відносин, особливостей управління в казахських ордах і прилеглих державних утвореннях. Казахи, як один із «малих народів» Російської імперії, підлягали поступовому і повному «ненав'язливому зросійщенню», як це відбувалося в той же час і з українцями, і з кримськими татарами, і 3 грузинами. Показово, що в текстах царських грамот, наданих казахським жузам при входженні їх до складу Росії, містилося словосполучення «природні піддані» (тобто росіяни). Попри те, що поняття росіян як етнічної цілісності вельми аморфне і умовне, ця велика група населення імперії протиставлялася всім іншим національностям і апріорі височіла над ними.

Згадана вище характеристика росіян як «природних підданих» використовувалася в царських грамотах в контексті проголошення рівності в статусі казахів і «корінного» населення Російської імперії. Таке формулювання виступало передусім не «гарантією безпеки» для казахів, як писалося в документах, а підставою для поступового обмеження і ліквідації традиційної ханської влади в жузах, а також введення там царської адміністрації в подальшому. Якщо до 1784 р. казахи перебували у віданні Колегії закордонних справ, то 3 цього року указом Катерини II управління їх територіями було передано відомству внутрішніх справ. Російські історики характеризують цей факт як нібито бюрократичну помилку, яку імператриця формально усунула своїм рішенням. Зауважимо, що схожа ситуація мала місце і щодо гетьманської України, включеної до складу імперії в 1781 році. Слід також врахувати, що такому рішенню царського уряду щодо казахів сприяли, серед іншого, факти активної участі останніх у повстаннях на чолі з О. Пугачовим у 1773-1775 pp., а також під проводом представника ханської верхівки С. Датова у 1783-1797 роках.

Змінивши підпорядкування казахських жузів (в урядових документах вони іменувалися ордами), імперська верхівка приступила до відкритого втручання у справи їх місцевого управління. Так, наприклад, істотно розширилася компетенція генерал-губернаторів, що відали справами казахів. Розглянемо в цьому контексті Указ Катерини II «Про забезпечення порядку в казахському степу, безпеки кордонів, ханської влади, призначення мулл у казахські орди та ін.», виданий особисто Симбірському і Уфимському генерал-губернатору 27 листопада 1784 року10. Основні положення цього документа зводилися до того, що вся цивільна, військова i духовна влада в регіоні була зосереджена в руках генерал-губернатора. 3 огляду на більш ранню тотальну ісламізацію регіону за рішенням тієї ж Катерини II указ закріплював механізм призначення мулл - духовних осіб в ісламі. Відбір кандидатур мав здійснюватися з числа казанських татар, які проявили себе благонадійними на російській службі. Також під верховенством генерал-губернатора мала бути створена комісія для вирішення прикордонних суперечок між казахами, киргизами і кайсаками (по суті російський чиновник повинен був контролювати дотримання прикордонного режиму з боку іншої держави). Далі, була пряма вказівка зменшити впливовість казахських родів і не допустити змови з ними затвердженого Петербургом хана.

Згідно з названим указом у разі непокори хана і султанів генерал-губернатор отримував право «дати їм відчути, що вони... не гідні ніякого покровительства», і що застосовувані ним для цього засоби нічим не обмежувалися. Також він був зобов'язаний при розгляді кандидатури нового хана досконально вивчати його біографію «через конфідентів» (тобто негласним шляхом), насамперед - на предмет лояльності до царського 
режиму. Казахська знать підлягала залученню до служби в російському війську в повному складі із наданням привілеїв, види і розміри яких повинен був встановлювати генерал-губернатор особисто - як наказувала імператриця, у цьому питанні «на винахідливість Вашу покладаємося». Крім цього, він повністю сам займався питаннями судочинства, світських і релігійних навчальних закладів у регіоні. Нарешті, разом із охороною державного кордону на генерал-губернатора покладалося «приборкання тамтешніх свавільних народів» - киргизів - під приводом захисту казахів від грабіжницьких нападів з їхнього боку, що, по суті, передбачало подальшу цілеспрямовану ліквідацію їхньої національної ідентичності.

Царські грамоти про прийняття казахських жузів до складу Російської імперії передбачали досить обмежену компетенцію російської адміністрації на їх території. У цілому ж пропонувалося збереження традиційної системи управління, яка б підпорядковувалася російським властям. Однак після вищеописаних подій 1784 р. росіяни стали різко обмежувати автономні права казахів, не зупиняючись і перед відвертими порушеннями приписів власних же грамот. Так, наприклад, уже Павло I у 1799 р. видав указ «Про підсудність убивств, скоєних казахами, законам Російської імперії»11. Згідно з указом, покарання за вбивство для казахів повинні були застосовуватися відповідно до російського законодавства і виконуватися лише представниками російської адміністрації - губернськими правліннями і першими департаментами палат місцевих судів. Відповідно, сам судовий розгляд також мав проходити згідно з російськими законами, а не місцевими казахськими, киргизькими і кайсацькими звичаями. Виходячи з тексту аналізованого указу, російське законодавство серед інших покарань за вбивство передбачало застосування заслання на каторгу. Очевидно, це був додатковий захід із асиміляції місцевого населення.

Посилення тенденцій щодо обмеження автономних прав казахів напередодні й після згаданих подій 1784 р. пояснюється, головним чином, особливостями нового політичного курсу імператриці Катерини II, котра зійшла на престол у 1762 році. Вона сама сформулювала «п’ять предметів»12, що становили іiі «правила управління» - російський варіант «освіченого абсолютизму». По-перше, керована монархом нація повинна бути освіченою. По-друге, законослухняність підданих є основою порядку в державі. По-третє, цьому сприяє також запровадження «хорошої і точної поліції». По-четверте, діяльність монарха повинна бути спрямована на те, щоб зробити свою державу багатою. По-п’яте, нарешті, «потрібно зробити державу грізною самою по собі та такою, котра викликає повагу сусідів». При цьому була зроблена примітка про те, що первинним для всіх підданих було усвідомлення обов'язку перед «Вищою Істотою». Зберігалися підходи часів Петра I щодо того, що служіння державі трактувалося через служіння Богу, а тому вважалося богоугодною і священною діяльністю.

Принцип щодо «грізності і навіювання» сягає корінням ще часів давньоіндійської «Артхашастри» трактату про мистецтво політичної діяльності й державного управління, - що додатково підтверджує тенденцію до архаїзації в політичній системі Російської імперії. Згідно з текстом цього трактату, мирні договори повинні були укладатися тільки з рівними за статусом або сильнішими правителями, а на слабкі держави потрібно нападати. Також невідомий автор «Артхашастри» писав, що мудрим є лише той правитель, який зміцнює власну державу і перешкоджає процвітанню інших. Подібне положення було закладено в основу державної ідеології держави Чингісхана - Монгольської імперії. Так, в одному з його указів проголошувалося, що монголи до часу занепаду своєї держави мають підпорядкувати собі весь світ і не повинні перебувати в мирі ні з яким народом, який не забажає добровільно їм підкоритися. По суті, йшлося про те, що саме в цьому і полягав сенс існування держави монголів, що саме за рахунок завоювань вона повинна була існувати до часу свого падіння. Обожнювання правителя також походило від монгольської ідеології, а не лише від концепції «Москва - Третій Рим», покладеної в основу ще московської, а потім і російської державницької ідеології. Так, до нас дійшли такі слова Чингісхана: «Бог - на Небі. Ха-хан - Могутність Божа на Землі. Вічно Синє Небо повеліло мені правити всіма народами»13. Очевидно, що сенс існування російської держави і сутність ії державного механізму трактувалися подібним чином протягом усього часу ії існування, що всього лише більш чітко було виписано Катериною II. Повага через страх - саме цей постулат був закладений в основу російської політики з «охорони кордонів», яку багато російських і радянські історики називають основним приводом до початку активних завойовницьких дій щодо казахських жузів.

Такий же принцип був покладений в основу існування і Золотої Орди - правонаступниці Монгольської імперії, у безпосередній васальної залежності від якої протягом століть перебували московські князі. Це держава, утворена в середині XIII ст., продовжувала курс на завоювання все більшої і більшої кількості земель. У XV ст. Золота Орда здобуває більш-менш чіткі межі і проголошує іслам державною релігією, намагаючись використовувати його потенціал для централізації влади хана - «першого серед рівних». Однак процес розпаду виявився неминучим. За подібною схемою розвивалася також і історія Росії: укріпленим і розвиненим став лише довколишній до столиці центр, приєднані ж території піддавалися лише експлуатації, але не опіці та облагородженню. Так, наприклад, казахський традиційний устрій було зруйновано за часів перебування жузів у складі Російської імперії, а введення елементів загальноросійського пристрої включало лише механізм тотального контролю над територією. Тому специфіка процесу інкорпорації казахських жузів Російською імперією не в останню чергу обумовлена тим, що як свого часу Казахське ханство, так і Московське князівство запозичили систему принципів побудови державного ладу і організації суспільства від однієї і тієї ж держави, якою була Золота Орда.

Закріпившись на казахських територіях в адміністративному відношенні, росіяни розгорнули й інші напрями експансії. Важлива роль у цій сфері була відведена освіті. У 1817 р. в Оренбурзі відповідно до наказу генерал губернатора П. Ессена було засновано військове училище, яке діяло в режимі повного пансіону для казахських хлопчиків у складі 40 осіб ${ }^{14}$. Серед предметів, які викладалися в училищі, були такі: основи християнської і мусульманської релігії, російська мова, іноземні мови (татарська, перська, арабська, німець- 
ка і французька), історія, географія, природна історія, початкові основи фізики і чиста математика. Після закінчення училища випускникам присвоювалась кваліфікація перекладача зі східних мов і офіцера регулярних військ. Передбачалося направлення їх до місцевого Оренбурзького корпусу для подальшого проходження служби.

Одним із перших кроків влади щодо впровадження експансіоністської політики в Казахстані також було видання 22 липня 1822 р. імператорського «Указу про введення в дію статуту про сибірських казахів»15. Цей документ передбачав створення в Сибіру для контролю над казахами Західного і Східного управлінь 3 центрами в Тобольську та Іркутську відповідно. Очолювали ці управління генерал-губернатори. Західне управління контролювало Тобольську, Томську й Омську губернії, а Східне - Іркутську і Єнісейську губернії, а також Якутську область (об'єднувала Охотське і Камчатське приморські управління). Губерніями, як і по всій Росії, управляли генерал-губернатори і цивільні губернатори. Обов'язком перших, серед іншого, було самостійне визначення меж своїх губерній. Підкреслювалося також, що для управління названими губерніями повинні бути видані спеціальні положення, а до цього генерал-губернатори повинні були керуватися загальними нормативними документами (але на практиці такий порядок залишився незмінним). Крім цього, докорінно змінювалася структура систем місцевого управління. Не оминули своєю увагою росіяни і природних ресурсів керованого краю: згідно з п. 14 Указу, у відання нової адміністрації передавалося і управління гірськими заводами разом із приписаними до них селянами. Однак фінансування управління сибірськими казахами здійснювалося за рахунок бюджету Іркутської губернії, тобто за залишковим принципом.

У підпорядкуванні казахів загальноросійській системі управління важливе значення мало запровадження порядку переходу до неї від місцевих традиційних укладів. Наприклад, у 1824 р. відбулося прийняття і впровадження «Затвердженої позиції Комітету азіатських справ щодо перетворення управління Оренбурзьким краєм»16. Метою авторів цього документа був перегляд традиційної системи управління, що склалася в Молодшому жузі. Відповідно до їхніх міркувань, система управління краєм повинна мала бути подібною до загальноросійських зразків. Водночас передбачалися винятки лише для прикордонного управління. Особливий характер управління Оренбурзьким краєм виявлявся, зокрема, у лінійній системі управління, що передбачала його поділ на дистанції на чолі зі штаб-офіцерами. До предмета відання останніх, серед іншого, належало «виконання особливих доручень начальства», яке відкривало простір для реалізації каральних задумів царського уряду. Лінійне управління становило прикордонну область, розділену на округи. Планувалося створити 12 округів, і казахи мали проживати компактно тільки в межах трьох із них.

Паралельну систему становило степове управління. До нього входили органи управління аулами, племенами і «частинами орди». Кожною частиною орди повинні були керувати хан і старший султан, i при кожному 3 них створювалася рада в якості погоджувального органу. При цьому компетенція цих органів разом iз радами не розмежовувалася взагалі. Також при кожному із старших султанів належало утримувати загін козаків, надісланих, очевидно, з інших регіонів. Надалі передбачався поділ Молодшого жуза (у документі вживається термін «орда») на три частини, якими керували б головні султани - представники роду Абулхаїра, які довели свою відданість царському уряду. Сфера застосування російських законів щодо казахів у першій чверті XIX ст. істотно розширювалася. Так, наприклад, оренбурзький генерал-губернатор П. Ессен у своєму розпорядженні в Оренбурзьку прикордонну комісію від 26 січня 1823 р. вказав, що покарання казахів за перехід через кордон повинно було здійснюватися за загальноросійськими законами ${ }^{17}$. Більше того, справи ці мав розглядати суд російський, а не традиційний казахський.

Територія Молодшого жуза становила сама по собі значний інтерес як для російського уряду в цілому, так і для козацьких загонів. Казахські степи, більшою мірою не обжиті, ідеально підходили на роль козацької вольниці. Козаки самовільно організовували і здійснювали деструктивні дії проти казахів, щоб спонукати їх залишити свої території. Зокрема, зафіксовано випадок нападу на торговий караван у складі 200 в'ючних верблюдів і повного його розграбування. Також султан Західної орди Чингалій Урманов був звинувачений у нецільовому використанні земель на березі Уралу для побудови власного житлового будинку. Очевидно, що це була територія, котра становила господарський і воєнний інтерес для росіян.

Таким чином, проведене дослідження доводить, що експансія Російської імперії в Казахстані здійснювалася в рамках ії загального геополітичного курсу, базованого на ідеологічній концепції «Москва - Третій Рим» та успадкованих від монголо-татарських державних утворень принципах ведення зовнішньої політики (завоювання - сенс існування держави, упокорення інших народів через страх, «божественне» схвалення такої діяльності). Контакти між московською державою і казахами відбувалися ще задовго до включення їхніх територій до складу Російської імперії. Остання ж, оцінюючи стратегічну важливість цього регіону для себе, поступово нарощувала там свою присутність і вплив. Обумовленість експансії переважно економічними факторами (вихід на азійський ринок) виключала необхідність збереження традиційного казахського ладу, а тому після включення всіх жузів (Молодшого, Середнього та Старшого) до складу російської держави сформовані там традиції суспільно-економічного устрою та управління поступово руйнувалися. Новий устрій цих територій відзначався підвищенням ролі та місця військовослужбовців у керівництві ними. Казахи як нація підлягали компактним переселенням, виселенням зі звичних місць кочівлі та покаранням виключно за російськими законами (місцеве звичаєве право цілеспрямовано виводилося з ужитку), а судовий і військово-адміністративний устрій у жузах запроваджувався за загальноросійським зразком. Подальшу перспективу досліджень із заявленої тематики ми пов'язуємо із залученням до наукового обігу більшої кількості першоджерел, які наразі ще не опубліковані та відсутні у вітчизняних архівних і бібліотечних фондах. 
1 Махашев Х. Проблемы вхождения Казахстана в Россию в дореволюционно-буржуазной историографии. Проблемы истории русско-казахских взаимоотночений в XVIII - начале XX веков. Алма-Ата, 1980. С. 107-114.

2 Асфендиаров С.Д. История Казахстана (с древнейших времён). Алма-Ата - Москва : Казахское краевое издательство, 1935. $261 \mathrm{c}$.

3 Аполлова Н.Г. Экономические и политические связи Казахстана с Россией в XVIII - начале XIX в. Москва : Изд-во АН CCCP, 1960. $430 \mathrm{c}$.

${ }^{4}$ Басин В.Я. Казахстан в системе внешней политике России в первой половине XVIII века. Казахстан в XV-XVIII веках (Вопросы социально-политической истории). Алма-Ата : Наука, 1969. С. 50-145. $247 \mathrm{c}$.

5 Сулейманов Б.С., Басин В.Я. Казахстан в составе России в XVIII - начале XX века Алма-Ата : Наука КазССР, 1981. $571 \mathrm{c}$

6 Див., напр.: Казахско-русские отношения в XVIII-XIX веках (1771-1867 годы): сб. док. и матер Алма-Ата : Наука, 1964.

${ }^{7}$ Сулейманова С.Ю. История тюркских народов (с древнейших времён по настоящее время) : уч. пособ. для студ. высш. учеб. завед. Баку: «Тэсхил» ИПП, 2000. С. 118-119.

${ }^{8}$ Материалы по истории политического строя Казахстана (со времени присоединения Казахстана к России до Великой Октябрьской социалистической революции) / сост. М.Г. Масевич. Алма-Ата: Изд-во АН КазССР, 1960. Т. 1. С. 12-13, 37-38, $53-54$.

9 Асфендиаров С.Д. Указ. соч. С. 107-108

10 Материалы по истории... С. 41-44.

11 Там само. С. 44-45.

12 Екатерина II. О величии России. Москва : Эксмо, 2006. С. 68.

13 Хара-Даван Э. Чингиз-хан как полководец и его наследие. На стыле континентов и цивилизаций... (из опыта образования и распада империй X-XVI вв.). Москва : ИНСАН, 1996. С. 126.

14 Материалы по истории... С. 235-236.

15 Там само. С. 91-92.

16 Там само. С. $205-210$.

17 Там само. С. 236-237.

\section{Резюме} XIX ст.).

Іванов О.Ю. Ідеологічні та політико-правові засади російської експансії в Казахстані (1714 р. - перша половина

У статті проаналізовані методи, застосовані Російською імперією при здійсненні експансії щодо Казахського ханства та його подальшої інкорпорації. Окрему увагу приділено ідеологічній основі російської державності, яка обумовила специфіку суті цих методів та нормативного забезпечення їх реалізації.

Ключові слова: Казахське ханство, Російська імперія, експансія, жузи, ідеологічна основа.

\section{Резюме}

Иванов А.Ю. Идеологические и политико-правовые основы российской экспансии в Казахстане (1714 г. - первая половина XIX в.).

В статье проанализированы методы, применяемые Российской империей при осуществлении экспансии по отношению к Казахскому ханству и его дальнейшей инкорпорации. Особое внимание уделено идеологической основе российской государственности, обусловившей специфику сущности этих методов и нормативного обеспечения их осуществления.

Ключевые слова: Казахское ханство, Российская империя, экспансия, жузы, идеологическая основа.

\section{Summary} tury).

Oleksandr Ivanov. Ideological and Political Legal Bases for the Russian Expansion in Kazakhstan (1714 - mid-XIX cen-

The article deals with the methods used by the Russian Empire for the expansion towards the Kazakh Khanate and its future incorporation. Special attention is drawn to the ideological bases of the Russian statehood caused peculiarities of those methods' contents and normative background for their implementation.

The Kazakh Khanate was founded in 1465. There were united diversified tribes having complicated administrative systems and quite different economic specializations. Several decades later khanate was divided into three various subjects called juzes. There were created Minor, Middle and Senior juzes. Each of them occasionally had economic and political relationships with the Moscow Tsardom. That state leaders found out the great strategic interest the Kazakh steeps posed for them. Peter the Great, the first Russian emperor proclaimed in 1721, looked for the new trade way to India. The Kazakh territories fit well enough for that goal. That's why there were arranged two military expeditions to examine possible means to create that way and to settle well-equipped fortresses along the rivers Amu Darya and Sirdarya. During the reign of Anna (1730-1740) the Minor (1731) and the Middle (1740) juzes were incorporated into the Russian Empire due to their requests. The Senior juze was incorporated in 1818 under the reign of Alexander I without any requests. Each juze was given a charter guaranteeing its status within the empire and proscribing obligations as a pay for the emperor's adherence to them

The Russian Empire authorities used all the possible means to break traditional Kazakh governing bodies, customs, land use system and culture. There were special Emperor's rescripts implementing militarized system of government for juzes and establishing allRussian courts' jurisdiction there. Local legal customs were being gradually excluded from use. Such way measures collided with charters given to juzes after their incorporation. They were aimed to make Kazakhs and their territories unalienable integrated parts of the Russian Empire. Its state policy was based on the ideological principles dating back to the Mongol-Tatar statehood and to the concept of "Moscow - the Third Rome".

Key words: the Kazakh Khanate, the Russian Empire, expansion, juzes, ideological basis. 